\title{
Waterscape, State and Situation of China's Water Resources
}

\section{Kwabena Agyarko Sarpong1, Wanzhen $\mathrm{Xu}^{1 *}$, Julius Mensah-Akoto², James Kortey Neequaye3, Adelaide Angela Dadzie ${ }^{1}$, Obeng Frimpong ${ }^{4}$}

\author{
${ }^{1}$ School of the Environment and Safety Engineering, Jiangsu University, Zhenjiang, China \\ ${ }^{2}$ Graduate School of Life and Earth Sciences, University of Tsukuba, Ibaraki, Japan \\ ${ }^{3}$ Department of Development and Environmental Studies, Wisconsin International University College, Accra, Ghana \\ ${ }^{4}$ Department of Silviculture and Forest Management, Kwame Nkrumah University of Science and Technology, Kumasi, Ghana \\ Email: *xwz09@ujs.edu.cn
}

How to cite this paper: Sarpong, K. A., Xu, W., Mensah-Akoto, J., Neequaye, J. K., Dadzie, A. A., \& Frimpong, O. (2020). Waterscape, State and Situation of China's Water Resources. Journal of Geoscience and Environment Protection, 8, 26-51.

https://doi.org/10.4236/gep.2020.810003

Received: September 4, 2020

Accepted: October 12, 2020

Published: October 15, 2020

Copyright $\odot 2020$ by author(s) and Scientific Research Publishing Inc. This work is licensed under the Creative Commons Attribution International License (CC BY 4.0).

http://creativecommons.org/licenses/by/4.0/

\begin{abstract}
Water is one of the most critical issues of concern in China's ongoing rapid economic development. The resource is scarce and demand is growing as China becomes more industrialized and urbanized. The situation is exacerbated by natural and anthropogenic events such as climate change, pollution, exorbitant patterns of water consumption, and an uneven distribution of water resources, with devastating impacts on ecosystems, international relations, food security and public health. In this paper, an overview of China's water resources is presented. Studies on distribution, consumption patterns and pollution of water resources are reviewed in order to understand the over-exploited and unexplored dimensions of the Chinese water landscape. The status of water resources is also studied with an intention of providing information on the dynamics of water quality and quantity. The paper concludes with a discussion on China's commitment to rebalancing its water growth model and the measures taken to achieve that.
\end{abstract}

\section{Keywords}

China, Water Consumption, Climate Change, Pollution, Population

\section{Introduction}

The escalating pace, intensity and scale of China's economic growth and urbanization have burdened the country's natural resources, including water. Although China has some 2.8 trillion cubic meters of water resources (Ministry of Water Resources, 1987), it faces regional water crisis. With a per capita standard of over 2000 cubic metres (Shi, 2020), the country's seemingly abundant water 
resources are well below the global average (3776 cubic metres) and close to a fifth of the US average (9459 cubic metres) (China Power Team, 2020). Additionally, the assessment of water-stress on the basis of the ratio of water availability to the amount of water withdrawal identifies China as the $56^{\text {th }}$ most water-stressed country in the world and thus, a water-scarce country (World Resource Institute (WRI), 2020). In some regions, water supply capacities can hardly meet demand, which invariably leads to poor and inadequate access to quality water. Indeed, China is in the throes of water crisis and this could be argued from the standpoint of the country's years of dramatic industrial development, unregulated agricultural expansion, population growth, and a demand for higher living standards (Zhou et al., 2017; Guan et al., 2014; Jusi, 1989; Liu \& Yang, 2012). Further to this, climate change, spatial heterogeneity and the uneven distribution of water resources exacerbate the problem (Sun et al., 2017; Cheng \& Hu, 2012).

Precipitation in the southern regions is relatively high and uniformly distributed throughout the year, while the absolute value of precipitation in the northern regions is lower and mostly intense in summer (Sun et al., 2017). Additionally, in the northern part of China, less than 13 percent of renewable freshwater baths and feeds many domestic, agricultural and industrial activities. However, the southern regions are rich in freshwater resources but do not match the distribution of the country's population and cultivable lands. Such inequalities in geographical distribution of water resources have occurred at the expense of the settlers in northern China, some of whom have been subjected to slow growth and abject poverty.

Moving forward, the remarkable economic development that has made China a model, setting off a new trial for the world, has only increased the thirst for water and made pollution more severe. The country's economic growth has relied on water and the resource has been consumed with little-to-no regard for potential demand (Economy, 2011; Peterson \& Stephenson, 1991). Economy (2011) further pointed out that, industries and agriculture are notoriously extravagant in water consumption, that is, industry accounts for about a quarter of China's overall water use and consumes four to ten times as much water per unit of GDP as other productive sectors. Similarly, irrigated agriculture has been a neck-breaking sector that has accounted for 62 percent of China's total gross water abstraction, and 84 percent of its net water abstraction (Gao et al., 2014; Hoekstra \& Mekonnen, 2012).

The extensive pollution adds to the scale of the water situation in China. Over the years, wastewater and sewage from industrial, domestic and agricultural discharges have gradually increased, causing many rivers and lakes to have water quality that is unsuitable for any use. Despite efforts by the Chinese government to improve water quality standards in recent years (Liu, 2015), pollution on some of the major rivers and lakes continues and the quality of these water resources is still below the grade levels of IV and V (water quality that is highly polluted and rarely used). This means that about 200 million people still use un- 
safe water (Gross, 2018).

These pollutions do not only overwhelm the fragile Chinese water landscape but also pose serious health complications. In northern China, water scarcity has increased the incidence of industrial pollution, overuse of agrochemicals and, at the same time, increased human exposure to toxic inorganic compounds (e.g. mercury, cadmium, lead, arsenic) given that, water-stressed farmers use polluted water for irrigation purposes. This leads to food contamination and a subsequent water-and food-related health emergencies. More than 11,000 water-related health emergencies have been reported since 1995. Many of these water-health implications have contributed to civil unrest (Gilbert, 2012).

The study proceeds against this background, with the aim of providing an overview of the country's water resources. Studies on distribution, consumption customs and pollution of water resources are reviewed in order to understand the over-exploited and unexplored dimensions of the Chinese water landscape. The status of water resources is also studied with an intention of providing information on the dynamics of water quality and quantity. The paper concludes with sustainable measures implemented by the Chinese government in addressing its water situation.

\section{Landscape of China's Water Resources}

\subsection{Climate and China's Water Resources}

In order to understand and appreciate the problem of water scarcity in China, a review of its climate, major rivers and lakes is imperative.

China, the third largest country in the world, holds about 20 percent of the human population and 6 percent of the world's water resources. China ranks $5^{\text {th }}$ next to Brazil, Russia, the United States of America (USA), and Canada (Figure 1). However, China's seemingly abundant water resources have been severely polluted, inefficiently utilized, and grossly overstretched, resulting in water shortages and limited supplies.

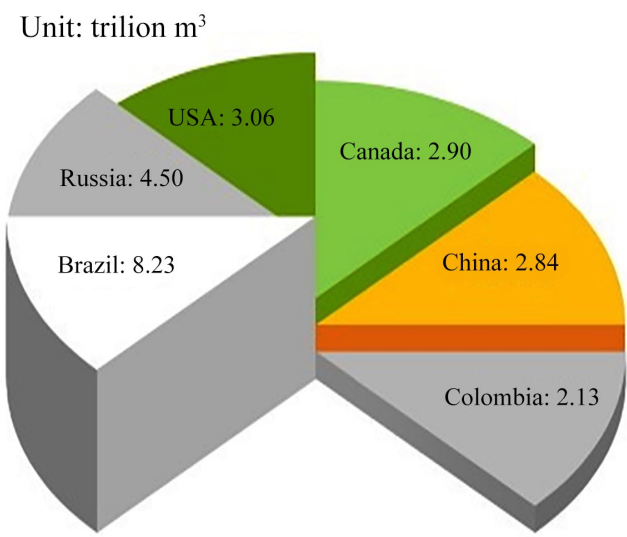

Figure 1. China's water resources of 2.84 trillion $\mathrm{m}^{3}$ and a summary of water resources of some countries around the world. 
Geographically, China has 21 river basins. Prominent amongst these rivers are the Yangtze, Yellow, Pearl, Hai, Liao, and Huai, Southeast, Southwest, and Northwest (Figure 2(a)). The Yangtze River divides the country into the dry north and wet south, and could be regarded as China's equator. The wet southern regions are below the Yangtze equator, and all regions above the equator are the dry north. A brief description and situational issues of the major river basins in the north and south are presented in Table A1 and Table A2.

China has more than 50,000 rivers with basin areas covering 40 square miles $\left(100 \mathrm{~km}^{2}\right)$ and 1500 rivers with individual drainage areas of $1000 \mathrm{~km}^{2}$. Most of these rivers are located in the south-eastern regions of China, where precipitation is plentiful. "Following the topography of the country, the total drainage area of the rivers flowing to the sea covers about 65 percent of the territory, with most of these flowing into the Pacific Ocean and small portion into the Indian Ocean and the Arctic Ocean. Endorheic river basins occupy the remaining 35 percent of the country's total area" (Food and Agriculture Organization (FAO), 2016). There are about 2800 lakes with an area of more than $1 \mathrm{~km}^{2}$. Most of these freshwater lakes spread along the middle and lower reaches of the Huai and Yangtze rivers in the east. Generally, the saltwater lakes are scattered along the Tibetan Plateau. Additionally, some 500 large-scale reservoirs and 3000 medium-scale reservoirs have been built with a total storage capacity of over 300 billion $\mathrm{m}^{3}$.

China's distribution of surface water is uneven and only few regions can boast of having enough quantities throughout the year. From the southeast to the northwest, surface water is seen to decrease as the terrain gets hilly and this accounts for some areas having little-to-no water all year round. However, most areas have abundant runoff, but it is only during the rainy summer when there is significant surplus of precipitation.

The varied landscape design and general topography of China also brings about the country's climate and uneven water dynamics. The shifting and strong monsoonal systems which mostly dominate the country's climate patterns characterize the wet summers and dry winters. Precipitation and climatic differences are thus seen to spread across the country's warm tropical and cold temperate regions.

Also, the availability and reliability of China's water resources are partly dependent on the country's annual precipitation, resulting in the variations in water quantity both in the northern and southern regions, given that the southern regions have the highest precipitation as compared to the northern regions. In the south-eastern regions, the total annual precipitation exceeds $2000 \mathrm{~mm}$ and is classified as the humid and semi-humid zones of the country (Figure 2(b)). These humid and semi-humid zones cover 53 percent of the country's area and account for 93 percent of its water resources (Table 1). However, the average annual precipitation in the north-western regions is mostly between $200-400$ $\mathrm{mm}$, indicating the water supply deficiency of the regions. These regions form 
the arid and semi-arid zones and cover 47 percent of the country's area with 7 percent water resources.

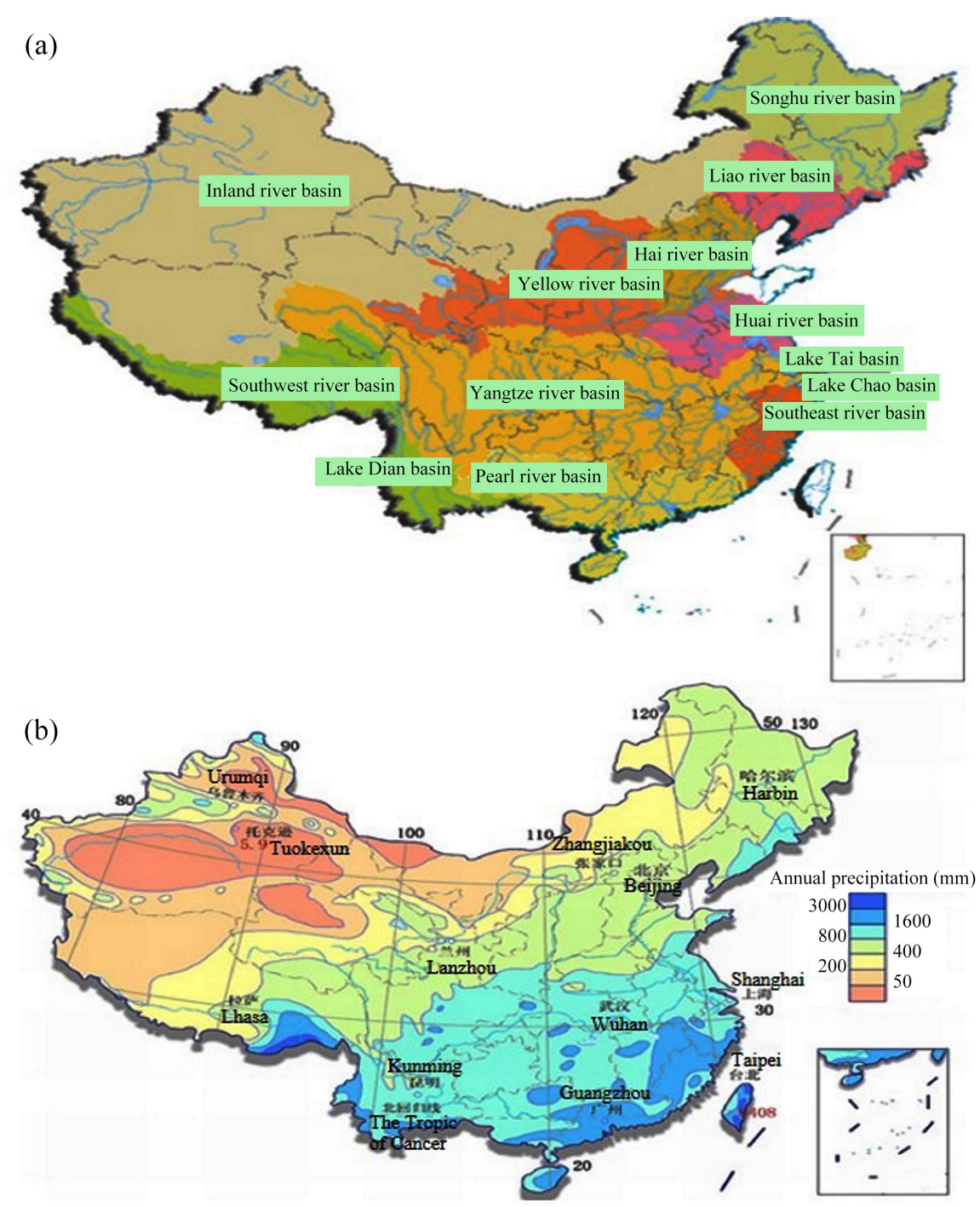

Figure 2. (a) Major river basins in China; and (b) long-term mean annual precipitation. Source: Cheng and $\mathrm{Hu}, 2012$.

Table 1. Climatic regions of China.

\begin{tabular}{ccccc}
\hline Regions & $\begin{array}{c}\text { Yearly amount of } \\
\text { rainfall }(\mathrm{mm})\end{array}$ & $\begin{array}{c}\text { Yearly amount of } \\
\text { run-off }(\mathrm{mm})\end{array}$ & Area (\%) & $\begin{array}{c}\text { Yearly amount of } \\
\text { water resources }(\%)\end{array}$ \\
\hline Arid & $<200$ & $<10$ & 26.6 & 2 \\
Semi-arid & $200-400$ & $10-50$ & 20.9 & 5 \\
Total & & & 47.5 & 7 \\
Humid & $400-800$ & $50-200$ & 18.6 & 12 \\
Semi-humid & $800-1600$ & $200-800$ & 26.0 & 58 \\
Extremely humid & $>2000$ & $>800$ & 7.9 & 23 \\
Total & & & 52.5 & 93 \\
\hline
\end{tabular}


The consecutive occurrence of dry periods and rainy periods often leave China exposed to extreme hydrological events such as floods, typhoons, droughts and waterlogging. Comparatively, the annual stream flow during the wet seasons to that during the dry seasons may be five times more in the southern regions and slightly above ten in the northern regions.

\subsection{China's Uneven Water Distribution}

Although China as a whole has a significant amount of water resources, the issue of uneven distribution, both temporally and spatially, mystifies national averages that indicate relative water abundance. Water availability varies significantly across the country due to differences in climate and topography. In general, there is more water in the south of China than in the north. This spatial disparity is inconsistent with the distribution of China's population and its overall productivity. Northern China accounts for 46.4 percent of the country's total population and 20 percent of its water resources. Southern China also accounts for 53.6 percent of the country's population and more than 80 percent of its water resources. As a result, the per capita water resource in northern China is about $747 \mathrm{~m}^{3}$, which is in sharp contrast to the $3481 \mathrm{~m}^{3}$ per capita levels in southern China.

This uneven distribution means that most northern provinces and important municipalities are water-stressed and face a potential threat of economic development (Table 2). Overall, nine provinces and municipalities suffer from absolute water shortages. All these places are in the north of China except Shanghai. Water supply is a problem even in flagship centres and cities. Population centres such as Beijing, Henan, Shandong and Hebei (with a total population of more than 250 million) are among the world's most water-stressed centres with less than 400 cubic meters of water/person/year-these results are comparable to countries in the Middle East and well below the threshold of "extreme water scarcity" of $500 \mathrm{~m}^{3} /$ person/year (Bray, 2018). For example, the 21.54 million people living in Beijing have to manage with less water than the people living in Saudi Arabia. In fact, Beijing is forced to cap its population at 23 million due to severe water shortages. Nevertheless, it is worth noting that, these northern provinces and municipalities account for $38 \%$ of China's agriculture, $46 \%$ of its trade, and $50 \%$ of its energy production (coal and nuclear energy consume large amounts of water) (Parton, 2018a).

\subsection{Climate Change and China's Water}

\subsubsection{Climate Change}

Globally, the phenomenon of climate change has been echoed by the fears of humanity coming to the brink of existence. The concern is that, emission levels continue to rise with barely a pause to allow the biological systems to adjust and disintegrate greenhouse gases (GHG), which are major contributors to climate change. As of 2017, Wong (2020) reported that, carbon dioxide emissions per capita had increased from 4.16 metric tons to 4.79 metric tons. This together with other GHG such as black carbon and nitrous oxide has been a reckoning 
Table 2. Provincial breakdown of water stress and scarcity.

\begin{tabular}{|c|c|c|}
\hline \multicolumn{3}{|c|}{ Low water stress provinces } \\
\hline Province & Per capita water resources $\left(\mathrm{m}^{3}\right)$ & Total water resources (billion $\mathrm{m}^{3}$ ) \\
\hline Tibet & $136,804.7$ & 465.82 \\
\hline Sichuan & 3548.16 & 295.26 \\
\hline Guizhou & 2726.18 & 97.87 \\
\hline Chongqing & 1697.22 & 52.42 \\
\hline Hubei & 1450.21 & 85.7 \\
\hline Anhui & 1328.88 & 85.58 \\
\hline Hunan & 1952.01 & 134.29 \\
\hline Jiangxi & 2479.18 & 114.91 \\
\hline Zhejiang & 1520.21 & 86.62 \\
\hline Guangxi & 3732.55 & 183.10 \\
\hline Fujian & 1982.93 & 77.85 \\
\hline Hainan & 4495.7 & 41.81 \\
\hline \multicolumn{3}{|c|}{ Low medium water stress provinces } \\
\hline \multicolumn{3}{|l|}{ Province } \\
\hline Heilongjiang & 2675.06 & 101.14 \\
\hline Qinghai & $16,018.32$ & 96.19 \\
\hline Jiangsu & 470.64 & 37.84 \\
\hline Yunnan & 4582.32 & 220.65 \\
\hline \multicolumn{3}{|c|}{ Medium water stress provinces } \\
\hline \multicolumn{3}{|l|}{ Province } \\
\hline Gansu & 1266.58 & 33.33 \\
\hline \multicolumn{3}{|c|}{ High water stress provinces } \\
\hline \multicolumn{3}{|l|}{ Province } \\
\hline Shanxi & 328.57 & 12.19 \\
\hline Ningxia & 214.6 & 1.47 \\
\hline Tianjin & 112.93 & 1.76 \\
\hline Inner Mongolia & 1823.03 & 46.15 \\
\hline Henan & 354.62 & 33.98 \\
\hline Xinjiang & 3482.56 & 85.88 \\
\hline \multicolumn{3}{|c|}{ Medium-high water stress provinces } \\
\hline \multicolumn{3}{|l|}{ Province } \\
\hline Shaanxi & 964.8 & 37.14 \\
\hline Jilin & 1775.32 & 48.12 \\
\hline Liaoning & 539.41 & 23.54 \\
\hline \multicolumn{3}{|c|}{ Extremely high-water stress provinces } \\
\hline \multicolumn{3}{|l|}{ Province } \\
\hline Shandong & 342.4 & 34.33 \\
\hline Hebei & 217.7 & 16.41 \\
\hline Beijing & 164.17 & 3.55 \\
\hline
\end{tabular}

Adapted from World Resources Institute; China Statistical Yearbook. 
force that has overwhelmed global surface temperature - researchers captured a rise in global surface temperature by about 0.82 degrees Celsius warmer in 2018 compared to the average in the twentieth century.

In China, the situation is no different. With nearly 27 percent of global GHG emissions (excluding land use, land use change and forestry) (Ritchie \& Roser, 2017), the country's average temperature rose by 0.24 degrees Celsius from 1951 to 2018 at a rate far higher than the global rise in average temperature (Xia et al., 2020). These changes also run parallel to global warming, though with some different characteristics. Between the 1920s to the 1940s, the average temperature in China first increased, followed by a decrease from the 1950s to the 1980s, and then increased from the mid-1980s to the present. While climate change and warm weather continue to affect China, extreme weather events and high temperatures are more pronounced in Northwest and Northeast-North of China. This pattern of temperature rise is reported throughout the year and continues to increase with severity, especially in the winters.

China's severe climate patterns and the incidence of natural disasters were anticipated to witness a downturn, with the country showing promising signs of decreasing carbon dioxide emissions. Nevertheless, disappointingly, rising fossil fuel usage has contributed to an estimated 2.3 percent increase in carbon dioxide emissions in 2018 and 4 percent in the first half of 2019, which is the third year of growth after emissions seemed to level out between 2014 and 2016 (Climate Action Tracker, 2020). This, along with past history of GHG and other anthropogenic activities, has come at a cost of rising summer heat waves, more frequent droughts (especially in northern China), heavy precipitation (especially in southern China) and widespread snow disasters. Further to this, China's average sea level and sea surface temperature have witnessed an accelerated upward trend over the last decade. It is estimated that from 1980 to 2018, sea levels rose by an average of $3.3 \mathrm{~mm}$ per year, while temperatures rose by an average of $0.37 \mathrm{C}$ per decade over the same period (Stanway, 2019).

The severity and frequency of some atmospheric and climate extremes are likely to worsen, with average temperatures rising from 1.3 to 2.1 degrees Celsius by 2020 and 2.3 to 3.3 degrees Celsius by 2050 (Luo et al., 2005). The intensity of the warming is assumed to increase from the southern to the northern regions of China. "Before the end of 2030, annual temperatures are projected to rise by 1.9 to 2.3 degrees Celsius in the northwest of China, by 1.6 to 2.0 degrees Celsius in the southwest of China and by 2.2 to 2.6 degrees Celsius in the Qinghai-Tibetan Plateau. Changes in precipitation are expected to assume an upward trend over the next 50 years, with forecasts of a $2-3$ percent increase by 2020 and a $5-7$ percent increase by the end of 2050" (Wang \& Zhang, 2011). Annual rainfall is possible to increase across the country's south-eastern coastal regions. These weather patterns and extreme changes in climate could disrupt socio-economic development. It is likely that there will be frequent and severe sand storms in the Northern Territory of the country, with less precipitation in the Eastern Coastal Areas, and more severe snow storms in both the Southern and Central Territo- 
ries. In view of the many uncertainties and complexities in climate forecasting, extensive studies and simulations are being conducted in China in conjunction with the IPCC Sixth Assessment Report (AR6).

\subsubsection{Impacts of Climate Change on Water Resources}

Climate change is partly responsible for the changing and uneven distribution of water resources across China. With changes in precipitation and increasing extreme weather events, major rivers in China have gradually receded over the last few decades. In particular, the Yellow River, the Huai River, the Liao River and the Hai River were reported to have decreased by 12 percent in 2007, with runoff reported to have been decreasing in the surrounding watersheds (China Daily, 2007). The shifting patterns of precipitation and long periods of drought are most evident in the arid regions of the country, with the Hai-Luan River basin being the most vulnerable to these changes, followed later by the Huai River basin and the Yellow River basin. The retreat and shrinking of the country's glaciers have also meant a decreasing volume in water quantity. With more than a third of China's glacier melting down to the heat of global warming, the country's water supply of glaciers, which is as much as that of the entire flow of the Yellow River, could have an impact on the headwaters hosted by the Qinghai-Tibetan Plateau (around 36,000 glaciers with an approximate land area of 50,000 kilometers) as they derive a substantial amount of water from these glaciers. Wetlands in the Qinghai-Tibetan Plateau are also shrinking due to climate change. In 2007, persistent changes in weather patterns over the last 40 years have resulted in a severe decline of almost 30\% of the Upper Yangtze wetland area (Gleick, 2009). Although precipitation has increased in the region, the loss has been more than offset by increased evaporation due to rising temperatures. Permafrost and vegetation loss are another report on the impact of climate change in the region.

\subsection{Pollution and China's Water}

Water pollution is an unavoidable problem in the growth of China's economy and population. However, the trend and scale of water pollution is worth considering provided that, a strain in the country's water supply will displace millions of people from their homes and have a remarkable effect on the country's economic development and urbanization. Although the Chinese government has made substantial investments in both the treatment and management of polluted waters, the country still had some 6.9 percent and 18.9 percent of its surface water below Grade-V and Grade IV-V levels respectively as of 2018 (Figure 3) (China Power Team, 2020). The shares of ground water pollution stood at 70.7 percent Grade-IV and 15.5 percent Grade-V levels in 2018 (Figure 4). Table 3 gives a clear explanation of the grade and quality level of China's water resources. These percentages of pollution for both ground and surface water resources are quite substantial and carry serious economic and social costs. 


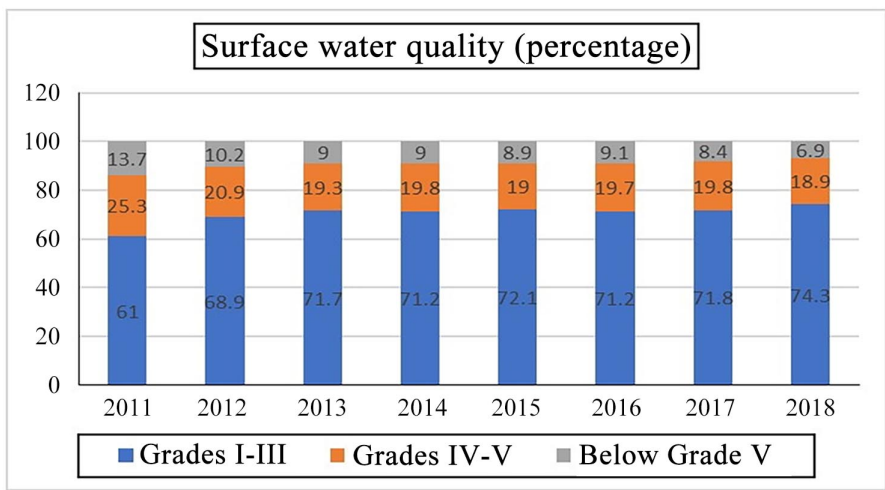

Figure 3. Breakdown of surface water quality in China from 2011-2018.

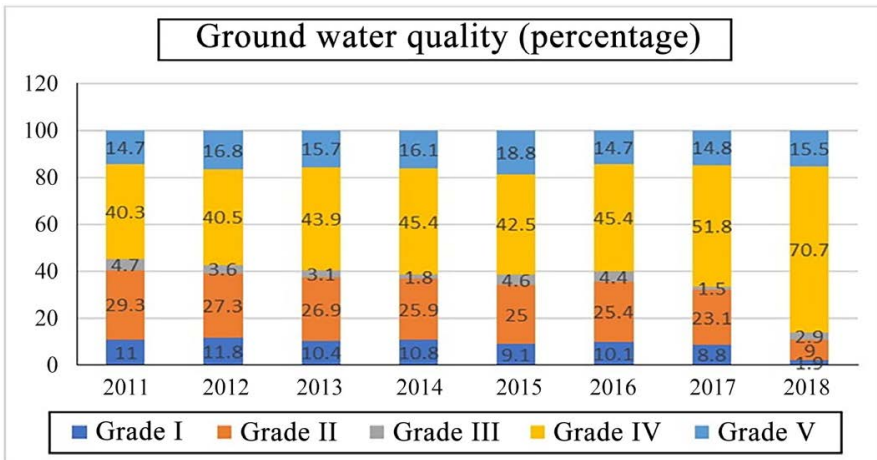

Figure 4. Breakdown of surface water quality in China from 2011-2018.

Table 3. China's water grading system.

\begin{tabular}{cc}
\hline Grade & Description \\
\hline I & Suitable for river sources and national natural reserves \\
II & Suitable for domestic use (first rate) and other uses \\
III & Suitable for domestic use (second rate) and other uses \\
IV & Suitable for industrial use which there and not for human contact \\
V & Suitable for agricultural use \\
Below V & Below function and unfit for use \\
\hline
\end{tabular}

Source: Ministry of Environmental Protection.

\section{China's Development and Water Use Patterns}

In situations where water resources are limited in space and time, effective and efficient use of the resource at minimal risk of scarcity is critical. However, with the rapid development of China's economy and the continued growth of its population, the problem of water scarcity is getting worse, especially in northern China, where there is a risk of serious water shortages. Total water usage has increased progressively at the national level, with the agricultural sector accounting for most of the use. As shown in Figure 5, total water consumption by sector increased from 443 billion cubic meters in 1980 to 588 billion cubic meters in 2018. Agriculture accounted for $63.0-88.2$ percent of the overall water consumption, with industrial use at $10.0-24.6$ percent and domestic use at $1.5-15.1$ 


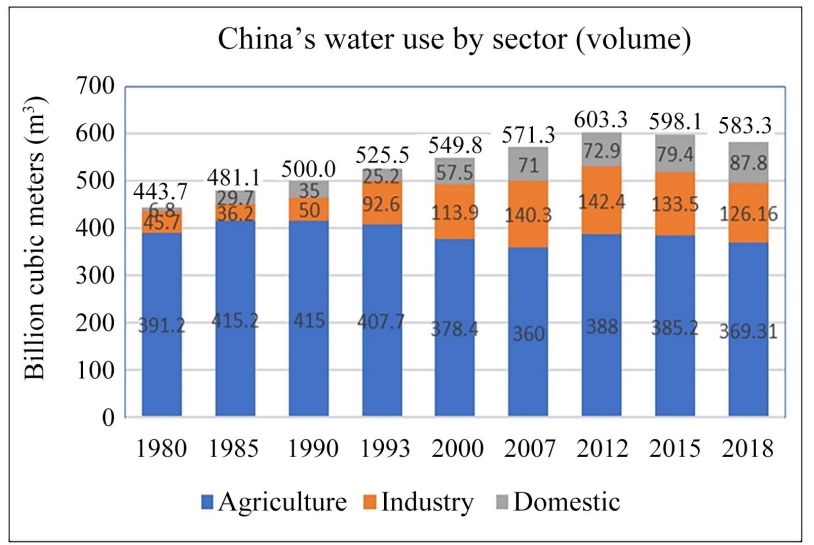

(a)

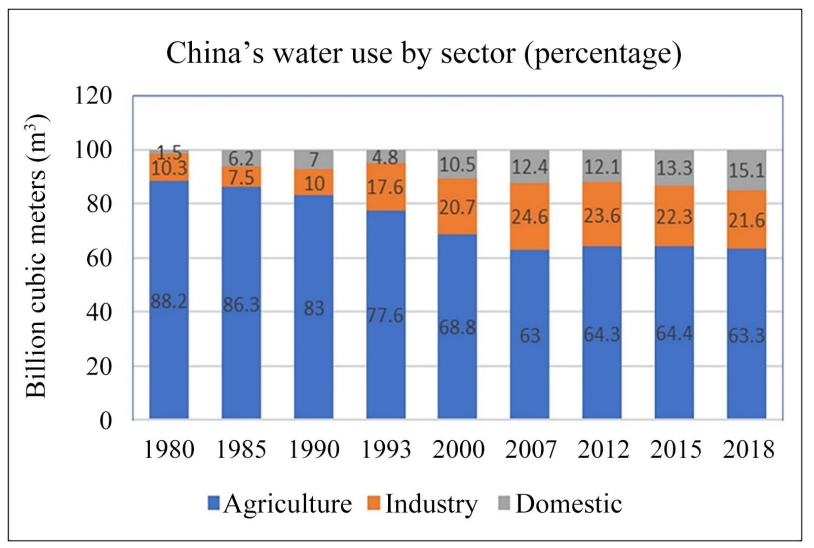

(b)

Figure 5. (a) Sectoral water use by volume; (b) Sectoral water use by percentage.

percent. Although agriculture accounts for most of China's water consumption, the sector's overall consumption decreased sharply from 1980 to 2014 (88.2 percent - 63.0 percent) and has seen a downward consumption trend since then. On the other hand, industrial and domestic water consumption has increased progressively, with the highest levels of use in both sectors being recorded in 2007 and 2018 respectively. This has largely been contingent on the explosion in the number of urban dwellers, increased affluence and disposable income, as well as water-intensive urban lifestyles.

Despite the decline in China's average water use per hectare of irrigated land (from $6750 \mathrm{~m}^{3} /$ ha to $5700 \mathrm{~m}^{3} / \mathrm{ha}$ in 2004-2016), the country lags almost a quarter more than the US average (China Water Resources (CWR), 2018a) and still has a substantial untapped potential in the reduction of water consumption (Huang et al., 2020). Conventional irrigation techniques such as border irrigation, check irrigation, and furrow irrigation are still used in agricultural production (Zhu et al., 2013) and these consume 10 - 30 per cent more water than modern drip irrigation (Grafton et al., 2018). At the same time, the substantial use of water in the agricultural sector is partly due to an increase in livestock production as a result of demand from growing urban populations. Livestock production has a much 
greater need of water: the production of $1 \mathrm{~kg}$ of animal protein may take many more litres of water than $1 \mathrm{~kg}$ of grain protein. In addition, the average water and energy consumption of urban residents is three times that of rural residents.

To determine water consumption in its socio-economic context, the study compares the annual changes in China's GDP, population, and water consumption from and in-between 1980 to 2018 (Table 4). The per capita consumption of water seems to increase as both population and GDP increases. Given the country's current water shortages and sustained population growth, this is certainly of concern. Furthermore, while the increase in water consumption comes from all sectors, domestic consumption has had a much faster increase and this could be associated to urbanization with a changing lifestyle and water use. Again, premium is mostly given to these two sectors when competition for water increases and agriculture is the sector most sensitive to water scarcity (Postel, 2000; Cai, 2008; Yin et al., 2017). The water consumption trend means greater competition for a limited amount of water between sectors.

The amount of water consumption at regional level is crucial in addressing China's water situation and could not be overlooked given that water is unevenly distributed throughout the country. In northern China, where the extremity of water shortages has been acknowledged, as of 2012, the region still used water exorbitantly for agricultural production, with proportions between 74 percent and 78 percent, much higher than the national level or the water-rich south (Jiang, 2015). Intensive irrigation continues to lower the water table by more than 40 metres, consequently causing irreversible damage to many ecosystems. In contrast to the declining water use for agricultural development in the south of the country, water use for agriculture in the north has increased. In fact, the proportion of agricultural water consumption in Southern China's overall water usage has actually been declining. Thus, sustainable water development in agricultural production is a prerequisite for achieving water security in northern China and the country as a whole.

Table 4. Annual percentage change of GDP, population, and water consumption over the period 1980-2018 in China.

\begin{tabular}{ccccccc}
\hline Year & $\begin{array}{c}\text { Population } \\
(\%)\end{array}$ & $\begin{array}{c}\text { GDP } \\
(\%)\end{array}$ & $\begin{array}{c}\text { Agriculture } \\
\left(\text { billion } \mathrm{m}^{3}\right)\end{array}$ & $\begin{array}{c}\text { Industry } \\
\left(\text { billion }^{3}\right)\end{array}$ & $\begin{array}{c}\text { Domestic } \\
\left(\text { billion }^{3}\right)\end{array}$ & $\begin{array}{c}\text { Total of sectorial } \\
\left.\text { consumption (billion } \mathrm{m}^{3}\right)\end{array}$ \\
\hline 1980 & 1.42 & 7.81 & 391.20 & 45.70 & 6.80 & 443.7 \\
1985 & 1.65 & 13.44 & 415.20 & 36.20 & 29.70 & 481.1 \\
1990 & 1.60 & 3.91 & 415.00 & 50.00 & 35.00 & 500.0 \\
1993 & 1.00 & 13.87 & 407.70 & 92.60 & 25.20 & 525.5 \\
2000 & 0.66 & 8.49 & 378.40 & 113.90 & 57.50 & 549.8 \\
2007 & 0.57 & 14.23 & 360.00 & 140.30 & 71.00 & 571.3 \\
2012 & 0.56 & 7.86 & 388.00 & 142.40 & 72.90 & 603.3 \\
2015 & 0.53 & 7.04 & 385.20 & 133.50 & 79.40 & 598.1 \\
2018 & 0.47 & 6.75 & 369.30 & 126.20 & 87.80 & 583.3 \\
\hline
\end{tabular}


As of 2016, China obtained about 82 percent of its water supply from surface water and 18 percent from groundwater (China Water Resources (CWR), $2018 b)$. However, the combined use of surface water and ground water showed a more dependence on the latter, given that water is unevenly distributed across the country. For example, the dry 11 regions (Beijing, Gansu, Hebei, Henan, Jiangsu, Liaoning, Ningxia, Shandong, Shanghai, Shanxi and Tianjin) are heavily dependent on groundwater with a resource utilization rate of about 28 percent compared to just 13 percent of the Safe 13 regions (Fujian, Hunan, Xinjiang, Guangxi, Jiangxi, Yunnan, Guizhou, Qinghai, Zhejiang, Hainan, Sichuan, Heilongjiang and Tibet). This implies that ground water reserves are declining at an exponential rate: "more than 230,000 square kilometers (sq.km) or about 4 per cent of China's land was over-exploited in 2015; the extent of exploitation on the Hai, Yellow and Liao, the three major northern rivers, was 106 percent, 83 percent and 76 percent against the internationally acceptable safety limit of 40 percent. The Yellow River, a source of support of northern China, flows only 10 percent as it did in the 1940s, and large areas are dry for most of the year" (Parton, 2018a). Considering that the current pattern of consumption is unsustainable, with an annual decrease of about 1 - 3 meters in ground water levels and a substantial decrease in national discharge, the natural system of water resources is subject to considerable pressure and aquifers are unable to fully recharge even with good rains threatening national water security.

The characterization and water use patterns as discussed above are suggestive of how critical it is to manage and keep consumption patterns at sustainable levels so as not to threaten the security of the already scarce water resources. Further development and incorporation of national water resources management based on the concept of sustainable development could be employed in the careful examination of water use implications in relation to the availability of water. Development of low utilization value but dependent on high water consumption should be minimized or avoided entirely.

\section{Implications and Consequences of China's Water Issues}

China has been the world's powerhouse of development, clothing and feeding countries with a range of products and services. Nevertheless, the many decades of rapid development and economic growth have not taken place without a toll on the country's natural resources, especially water. The concern now is that the reliance on water for growth far outweighs the resilience of the resource, and this pattern of over-exploitation, if continued, could lead to a severe water crisis that threatens the entire development of the country and the world. Conflicts in the distribution and use of water between the southern and northern regions of the country are bound to occur and may escalate if the north continues to depend more heavily on the water coming from the south. Further to this, competition among sectors for water rights and a larger share of the resource could intensify, inevitably leading to civil unrest. Countries in South and South East Asia (India, 
Bangladesh, Burma, Bhutan, Nepal, Cambodia, Pakistan, Laos, Thailand, and Vietnam) with part of their source of water flowing from the Qinghai-Tibetan Plateau could also be victims of China's water shortages. If water supplies from the Qinghai-Tibetan Plateau start to decline, China will be more likely to save and potentially store water for its citizens than for these countries. These countries are already grappling with polluted and declining water resources, and this could worsen should China redirect the flow of rivers that would supply much-needed water to these countries.

It could be argued that, China's unrestrained development and rapid population growth have contributed to undermining the integrity of its water systems and the pollution of its major rivers. The need for China to augment its water supplies now threatens the ecological sustainability of the network of river systems linked to South and Southeast Asia, given that, the country has an enormous need for water and energy. Tensions are already rising between China and India, the two Asian giants, following the construction of the Zangmu Dam by China at the end of 2014. The channelling and diversion of water that would have flowed to other countries, and also allowing more and more polluted water to flow through other countries, is but only a spring board that has fermented debate and political tension between China and neighbouring countries. It is also likely that, the large influx of people from extremely water-scarce communities into other countries could further enrage neighbouring countries and strain political ties. The water wars of the 21 st century have marked and replaced the oil wars of the 20th century and could continue until agreements and protocols are reached between China and its neighbouring countries.

Issues and contamination of China's water resources often pose risks to water quality with potentially significant human health threats. Conventional and emerging contaminants such as lead, arsenic, chromium, mercury, nitrite, excessive fluoride, endocrine disrupting compounds (EDCs), pharmaceuticals and personal care products (PPCPs), antibiotic resistance genes, and pathogens are linked to higher rate of cholera, tumours, typhoid, spontaneous abortions and all forms of cancers. In 2018, surveillance data from the National Health Commission of China registered 7.8 million cases of national infectious diseases, including 18.9 percent of waterborne diseases (National Health Commission, 2018). With increasing levels of pollution and non-compliance with the regulations, it is safe to assume that water-related diseases will increase. Currently, 5.5 percent of reservoir water sources and 16.1 percent of lake water sources in China do not comply with regulatory requirements (Ministry of Ecological Environment, 2018). Since the rivers of China flow through so many different regions, disease could easily be transferred to many people.

Issues related to water scarcity cut across all water consumption sectors and affect both inputs and outputs at the local and regional levels. With agriculture accounting for over half of China's water usage, the sector becomes the most vulnerable to threats of water shortage. Given that climate change will bring 
variations in weather patterns, precipitation and drought events, there will be significant changes across river basins and productive agricultural areas, particularly in the Hai and lower reaches of the Huang river basins, leading to an absolute decline in food production. The production of livestock, an exorbitant consumer of water, will also change. Considering the size and significance of China in the world food system, these changes could have an impact on international markets.

\section{Measures Taken by the Chinese Government in the Sustainable Development of Water Resources}

The World Commission on Environment and Development brought into existence an idea for sustainable development and this basically originated from the challenges inherent in the environment-development nexus. Prominent among the objectives of sustainable development is to preserve the world's water scarce resources for future generations (Portney, 2016; Wheater \& Evans, 2009; Brown et al., 2009). While the objective of sustainable water management is noble in all respects, the issue of concern is how this could be achieved without compromising on daily supply needs. In 2012, Jun (2012) argued that efforts to improve environmental sustainability in recent decades remain a daunting task and the looming water crisis appears to be a major threat to human survival. This issue, together with chronic water shortages, has led to scholarly work (see e.g. Patrick, 2011; Jha et al., 2007; Rogers \& Hall, 2003) and discussions on how to manage and protect water resources sustainably, particularly in developing countries. Pursuant to this and the goals of sustainable development, China has taken steps to develop a road map for the sustainable development and use of water resources. The next sections present the measures taken by the Chinese Government to address the water resource situation in China.

\subsection{Increasing Water Use Efficiency}

Cheng and $\mathrm{Hu}$ (2012) note that an effective strategy adopted by the Chinese Government to use and sustainably develop the country's water resources is through water efficiency. The need to use water sufficiently stems from the fact that the loss of water through transmission, over-exploitation and waste accounts for severe water shortages in China (Cheng et al., 2009). Reddy (2008) adds that the design and implementation of effective water management regimes in China would culminate in the saving of significant amounts of water that could be used by other sectors. This would eventually meet the needs of all sectors of the country's water supply. Further to this, the adoption of efficient ways to use water resources in the country has resulted in a gradual reduction in China's water consumption patterns, particularly in the agricultural sector.

Essentially, these gradual reductions have been achieved through wastewater recycling, championing water-saving technologies and increasing the efficiency of water use. Over the years, water pricing has also been reviewed in order to 
improve efficiency in the use of the resource, thus promoting sustainable development of water in the country (Zhong \& Mol, 2010). As highlighted by the World Bank (2007), a major cause of water-wastage and the unsustainable use of water resources in China is underpricing of water. Because water is relatively cheaper in China, compared to other nations, it does not only encourage water wastage, but also has far-reaching implications for the design and subsequent implementation of other equally important water-saving technologies (Cheng \& $\mathrm{Hu}, 2012$ ). Therefore, in order to maximize water resource efficiency and ultimately lead to sustainable water resource development in China, economic policy instruments, such as water price adjustment, have been put in place to suggest serious water resource shortages to consumers, thus providing a stimulus for water users to use water responsibly (World Bank, 2018).

In the context of water pricing, premiums are placed on fixing the right prices for water, controlling demand for water and fully recovering the costs of providing water services (Zhong \& Mol, 2010). By this and in order to ensure sustainable water development, the country has succeeded in developing an effective price index for water resources and introduced higher water user fees to conserve its scarce water resources. Ultimately, the country's determination to see these water efficiency reforms through could reduce water wastages, increase the quantity of water and eventually ease the tension between demand and supply.

\subsection{Introduction of Water Rights}

In the opinion of Walker (2015) water rights allow for the equitable distribution and good management of limited water resources. As a result, regional water rights, abstractor water rights and user-level water rights have been permitted in China as a creative approach to the sustainable development of water resources (Shen \& Speed, 2009). Over the years, China's introduction of the water rights trading scheme has achieved significant progress in its implementation. By 2018, an over-all of 88 transactions including some 2.75 billion cubic meters had been made and registered on the China Water Exchange (CWR, 2018b). The purpose of these transactions and their uniqueness is to promote, facilitate and ultimately compel water-rights holders to implement, monitor and enforce well-targeted policy initiatives that improve the effective and efficient use of water. Under the water-rights system, China envisages transferring rights to use water resources to areas and/or sectors where they are most needed, with the expectation that surplus water would be conserved and that this could be a possible solution to the problems of water scarcity in water stressed areas.

\subsection{Water Pollution Control}

Water pollution resulting from industrial, agricultural, and domestic activities have emerged as an important area of environmental concern to the Chinese government. The county has improved the regulation and treatment of water 
pollution and has taken steps to enhance sanitation. New commitments and efforts have been made to improve the capacity of cities and towns to prevent and control sewage. In doing so, the government by 2018 had installed some 4332 wastewater treatment plants in cities across the country, with an average treatment capacity of 195 million cubic metres (Ministry of Foreign Affairs-China (MFA-China), 2019). The pre-discharge treatment of water pollutants, the remediation of black smelly water bodies and the control levels of contamination have progressively increased within the years and as such, increased the proportion of good quality surface water by 74.9 percent as of 2019 , an increase of 3.9 percent. In addition, more than 97 percent of the country's regional and higher-level industrial clusters have constructed integrated sewage treatment facilities and installed automated online monitoring systems to avoid and manage water pollution (Ministry of Foreign Affairs-China (MFA-China), 2019).

When fully implemented, these pollution control measures by the Chinese Government could efficiently reduce and/or stop the discharge of municipal, industrial and agricultural effluents into water resources. This would protect the scarce water resources of the country from contamination, making large volumes of water available for domestic, industrial, agricultural and other equally important purposes. Minimizing and/or stopping pollutants from being discharged into water resources would also have an impact on the health and safety of water users. As water resources are less polluted, consumers and users are less likely to be affected by water-related diseases.

\subsection{Enhancing Coordination between River and Lake Chiefs and River Basin Commissions}

In order to promote the sustainable development of water resources in China, the Government has developed a new system to encourage the management and conservation of the country's major water supplies through the assistance of the River Chiefs (World Bank, 2018). The government extended this coordination to include major lakes and other water bodies through the Lake Chiefs. The World Bank (2018) further noted that, the coordination system is set to establish the river and lake chiefs at four distinct levels (provincial, municipal, county and township, and the village-level) to help achieve sustainable development of water resources.

To a larger extent, the river and lake chiefs are officials charged with the duty of providing oversight responsibility of every major river or lake. Also, the river and lake chiefs fortify enforcement and accountability issues regarding key sustainable water policy measures (World Bank, 2018). These chiefs are also responsible for meeting environmental preservation and water quality targets in their various locations. In addition, they play an instrumental role in sustainable water development efforts, such as the conservation of water, prevention of water pollution, protection of river banks and the facilitation of ecological restoration.

The Government's objective to create closer communication and cooperation 
between River Chiefs and River Basin Commissions was to ensure that River Chiefs are officially recognized as key officials with important roles to play in the sustainable development of water resources and to facilitate the successful implementation of established policies (World Bank, 2018). This coordination was also aimed at ensuring a healthier relationship between the River Basin Commission and the River Chiefs in order to build up a framework for effective decision-making. Specifically, this enhanced cooperation between River and Lake Chiefs and the River Basin Commissions is intended to result in the efficient management of the country's major water resources. Since River and Lake Chiefs control major water resources and are responsible for overseeing the management of water resources, this will translate into proper care and management. This is because River and Lake Chiefs are much closer to the key water resources and understand the local and contextual conditions very well. As a result, they are best positioned to establish and implement regulatory regimes that would improve the sustainable development and use of the country's water resources.

\subsection{Water Withdrawal Permits and Pollution Discharge Permits}

The implementation of a water withdrawal scheme (Wu et al., 2012; Sun et al., 2006) is an important technique used by the Chinese Government in the sustainable development of water resources. In this regard, water withdrawal licenses are valid for the extraction of groundwater from aquifers and/or running water from rivers and lakes (Han et al., 2016). It is therefore a legal requirement that, permits are obtained from authorities prior to the extraction of water. The World Bank (2018) pointed out that decisions on the allocation of water resources and the issuance of a withdrawal license are made on the basis of the state of water resources, which are primarily informed by background water assessments and surveys. Where it appears from the surveys and assessments that ground or surface water has been overdrawn, firm control on the water drawing would be imposed. It is important to note that where water withdrawals are intended for domestic use, livestock and poultry production, it is not generally mandatory to obtain permits from the regulatory authorities.

In addition, the country has set up a pollutant discharge permit system in its effort to facilitate the sustainable use of water resources. This system essentially prohibits the release of water pollutants into water resources and waterways without appropriate approval (World Bank, 2018). Due to the relevance of the pollution discharge permits, the MEP in 2017 made it a nationwide scheme. The amendment made it compulsory for all sources of water pollution to receive licenses before their pollutants are released into the water ways.

This measure has implications on the sustainable development of the country's water resources. Firstly, since water assessment surveys are conducted to determine the level of water available in underground and surface water, it effectively limits water extraction from overly drawn sources. This level of withdraw- 
al permit ensures that the excessively withdrawn water resources are left to regenerate in terms of their production capacity. The pollution discharge permits also ensure a reduction in the amount of pollutants discharged into water resources. This limits the health dangers associated with the consumption of these water resources and guarantees the safety of all water users.

\subsection{South-North Water Transfer}

The Ministry of Water Resources [MWR] (2002) pointed out that, the abundance of water resources in southern China, coupled with the severe shortage of water in the northern plain of the country makes it imperative for water to be borrowed from the south to the north. The proposal was put forward by Chairman Mao, leader of the country in the 1950's. Following his inspection of the Yellow River, Mao was convinced that the transfer of water from the south, where the resource is relatively abundant, could help alleviate the water supply challenges in the northern China (Yang \& Zehnder, 2005). However, at the time, the huge financial costs and complex technical issues associated with the project made it unrealistic (Yang \& Zehnder, 2005).

Nevertheless, China's rapid economic growth over the years has significantly increased its wealth, giving it the financial and technical capacity to implement the South-North Water Diversion (SNWT) project. The project is currently underway. By March 2019, the cumulative water diverted from the eastern and middle routes of the SNWT project had reached 23 billion cubic metres, significantly increasing the water supply capacity of Beijing and other major provinces and cities (Ministry of Foreign Affairs-China (MFA-China), 2019).

\subsection{Three Red Lines}

In addressing water challenges in China, the government has adopted a new approach based on the principles of the "Three Red Lines" namely "control of total water use, control of lower water efficiency and control of total wastewater load". This new approach, which is considered to be the strictest water control system, overlaps with China's policy on sustainable water resource development. This system of the "Three Red Lines" is set to ensure that overall annual water consumption reaches 700 billion cubic meters by 2030, that irrigation efficiency is increased and that the quality of water resources is protected (World Resources Institute (WRI), 2018). If the "Three Red Lines" principles are followed successfully, China's socio-economic development could match the country's water resources without putting pressure on it.

\subsection{Resource Water Conservancy}

China has set up river basin commissions which are also known as the water conservancy commissions. Such conservation commissions are mandated by law as the main planning entity for the numerous and major river basins in the country (World Bank, 2018). The Committee is responsible for ensuring the ap- 
propriate management and use of water resources in the different basins (World Bank, 2018). In an attempt to improve China's water resources sustainably, some authors (see e.g. Wang et al., 2009) note that it is important for the country to change its focus from the engineering aspect of water management to the conservation side of management. This initiative allows the country to step up its integrated management of water resources and with tremendous benefits (Huang et al., 2012).

Resource water conservancy is rooted in the concept of sustainable development and integrated water resources management (Liu et al., 2013). Under these principles, focus is placed on the efficient use of water and the protection of water by sustainable methods. The concept has thus been seen as an important measure to safeguard water resources. In Liu et al.'s opinion (2013), water conservation is an important mechanism that seeks to repair river banks, dredge flood channels and release flood disasters, thus, resulting in sustainable management of scarce water resources (Liu et al., 2013).

Resource water conservation has also been shown to have tremendous impacts on the production and consumption of China's water resources. First, since planning units are set up to oversee the management, conservation and use of water resources, they ensure that water resources are used in a rational manner. These planning units along river basins also ensure that pollutive tendencies in rivers are halted to ensure that clean water is provided. This reduces the safety risks associated with the use of contaminated water. Furthermore, as these planning units promote the protection and conservation of water resources, they ensure that sufficient quantities of water are available in the country for present and future generations.

\subsection{Water Resources Master Plan}

The China Water Resources Master Plan (CWRMP) was implemented in 2002 by the Chinese Ministry of Water Resources (MWR) to improve water crises faced in the country. The content of the master plan includes: 1) analyzing the current water situation under the rising challenge of climate change; 2) gathering sufficient information on the existing condition of the nation's water resources; and 3) outlining a 20-year strategic water strategy for the future. This master plan will ensure that sufficient background knowledge is obtained about the existing state of the nation's water resources. On this basis, sound and efficient policy mechanisms for the effective management of China's water resources could be developed and enforced.

\section{Conclusion}

China's rapid socio-economic growth has put tremendous pressure on the country in ensuring a reliable supply of water for household, industrial and agricultural use. However, severe water shortages in the country, particularly in the north, make it difficult for socio-economic development to keep pace with 
water development. In order to ensure a more sustainable and efficient consumption of scarce water resources, the country has implemented many measures. Typically, strategic measures such as water conservancy, water drawing permits, South-North Water Transfer Project among others have been implemented.

Despite all these significant efforts aimed at improving the sustainable development of water resources, the complex set of issues pertaining to water adequacy and quality still persist. On this basis, the government, policymakers and all related stakeholders in the water sector must carefully establish reforms and policies that incorporate the social, economic, environmental, technical and scientific dimensions of sustainable development and water resource use in the country. This could ensure sustainability in socio-economic development while ensuring sound and efficient management and use of the country's water resources.

\section{Conflicts of Interest}

The authors declare no conflicts of interest regarding the publication of this paper.

\section{References}

Bray, J. (2018). Examining Water Issues in China. http://sydney.edu.au/environment-institute/opinion/examining-water-issues-china

Brown, R. R., Keath, N., \& Wong, T. H. (2009). Urban Water Management in Cities: Historical, Current and Future Regimes. Water Science and Technology, 59, 847-855. https://doi.org/10.2166/wst.2009.029

Cai, X. (2008). Water Stress, Water Transfer and Social Equity in Northern China-Implications for Policy Reforms. Journal of Environmental Management, 87, 14-25. https://doi.org/10.1016/j.jenvman.2006.12.046

Cheng, H., \& Hu, Y. (2012). Improving China's Water Resources Management for Better Adaptation to Climate Change. Climatic Change, 112, 253-282. https://doi.org/10.1007/s10584-011-0042-8

Cheng, H., Hu, Y., \& Zhao, J. (2009). Meeting China's Water Shortage Crisis: Current Practices and Challenges. Environmental Science and Technology, 43, 240-244. https://doi.org/10.1021/es801934a

China Daily (2007). Warming Takes Toll on Water Resources. http://www.mwr.gov.cn/english/20071105/87684.asp

China Power Team (2020). How Does Water Security Affect China's Development? China Power. https://chinapower.csis.org/china-water-security

China Water Resources (CWR) (2018a). China Irrigation-Expanding Irrigated Land, Improving Efficiency \& Spending. https://www.chinawaterrisk.org/the-big-picture/china-irrigation

China Water Resources (CWR) (2018b). Water Rights in China: 4 Years on. https://www.chinawaterrisk.org/interviews/water-rights-in-china-4-years-on

Climate Action Tracker (2020). China. https://climateactiontracker.org/countries/china

Economy, E. (2011). China’s Growing Water Crisis. World Politics Review. 
https://www.worldpoliticsreview.com/articles/9684/chinas-growing-water-crisis

Food and Agriculture Organization (FAO) of the United Nations (2016). Aquastat. Water Resources.

http://www.fao.org/nr/water/aquastat/countries_regions/Profile_segments/CHN-WR_ eng.stm

Gao, H., Wei, T., Lou, I., Yang, Z., Shen, Z., \& Li, Y. (2014). Water Saving Effect on Integrated Water Resource Management. Resources, Conservation and Recycling, 93, 50-58. https://doi.org/10.1016/j.resconrec.2014.09.009

Gilbert, N. (2012). Green Protests on the Rise in China. Nature, 488, 261-262. https://doi.org/10.1038/488261a

Gleick, P. H. (2009). China and Water. In The World's Water 2008-2009: The Biennial Report on Freshwater Resources (pp. 79-100). Washington DC: Island Press.

Grafton, R. Q., Williams, J., Perry, C. J., Molle, F., Ringler, C., Steduto, P., Udall, B., Wheeler, S. A, Wang, Y., \& Garrick, D. (2018). The Paradox of Irrigation Efficiency. Science, 361, 748-750. https://doi.org/10.1126/science.aat9314

Gross, M. (2018). China’s Water Challenges. Current Biology, 28, R135-R138. https://doi.org/10.1016/j.cub.2018.02.001

Guan, D., Hubacek, K., Tillotson, M., Zhao, H., Liu, W., Liu, Z., \& Liang, S. (2014). Lifting China's Water Spell. Environmental Science and Technology, 48, 11048-11056. https://doi.org/10.1021/es501379n

Han, D., Currell, M. J., \& Cao, G. (2016). Deep Challenges for China's War on Water Pollution. Environmental Pollution, 218, 1222-1233. https://doi.org/10.1016/j.envpol.2016.08.078

Hoekstra, A. Y., \& Mekonnen, M. M. (2012). The Water Footprint of Humanity. Proceedings of the National Academy of Sciences of the United States of America, 109, 3232-3237. https://doi.org/10.1073/pnas.1109936109

Huang, G., Hoekstra, A. Y., Krol, M. S., Jagermeyr, J., Galindo, A., Yu, C., \& Wang, R. (2020). Water-Saving Agriculture Can Deliver Deep Water Cuts for China. Resources, Conservation and Recycling, 154, Article ID: 104578.

https://doi.org/10.1016/j.resconrec.2019.104578

Huang, Y., Li, Y. P., Chen, X., \& Ma, Y. G. (2012). Optimization of the Irrigation Water Resources for Agricultural Sustainability in Tarim River Basin, China. Agricultural Water Management, 107, 74-85. https://doi.org/10.1016/j.agwat.2012.01.012

Jha, M. K., Chowdhury, A., Chowdary, V. M., \& Peiffer, S. (2007). Groundwater Management and Development by Integrated Remote Sensing and Geographic Information Systems: Prospects and Constraints. Water Resources Management, 21, 427-467. https://doi.org/10.1007/s11269-006-9024-4

Jiang, Y. (2015). China's Water Security: Current Status, Emerging Challenges and Future Prospects. Environmental Science and Policy, 54, 106-125. https://doi.org/10.1016/j.envsci.2015.06.006

Jun, X. (2012). Science and Technology for Sustainable Water in China. Perspectives, 26, 4.

Jusi, W. (1989). Water Pollution and Water Shortage Problems in China. Journal of Applied Ecology, 26, 851-857. https://doi.org/10.2307/2403696

Liu, H. (2015). China's Long March to Safe Drinking Water. China Water Risk, 44, 1-44.

Liu, J., \& Yang, W. (2012). Water Sustainability for China and Beyond. Science, 337, 649-650. https://doi.org/10.1126/science.1219471

Liu, J., Zang, C., Tian, S., Liu, J., Yang, H., Jia, S., You, L., Liu, B., \& Zhang, M. (2013). 
Water Conservancy Projects in China: Achievements, Challenges and Way Forward. Global Environmental Change, 23, 633-643.

https://doi.org/10.1016/j.gloenvcha.2013.02.002

Luo, Y., Ding, Y. H., Zhao, Z. C., Gao, X. J., Xu, Y., \& Xie, Z. R. (2005). Projection of the Anthropologic Impacts on Climate Change. In D. H. Qin (Ed.), Climate and Environment Evolutions in China (pp. 507-555). Beijing: Science Press.

Ministry of Ecological Environment (2018). China's Ecological Environment Bulletin. http://www.mee.gov.cn/ywdt/tpxw/201905/t20190529_704841.shtml

Ministry of Foreign Affairs-China (2019). China's Progress Report on Implementation of the 2030 Agenda for Sustainable Development.

https://www.fmprc.gov.cn/mfa_eng/topics_665678/2030kcxfzyc/P020190924780823323 749.pdf

Ministry of Water Resources (1987). Water Resources Assessment in China. Beijing: Water and Hydropower Publishing.

Ministry of Water Resources (2002). Project Planning and Design Selection of the South-North Water Transfer. http://www.mwr.gov.cn/nsbdzt/jqgz/jagz3.htm

National Health Commission (2018). China’s Health Statistics Yearbook. http://www.tjcn.org/tjnj/www/37967.html

Parton, C. (2018a). China Is Heading towards a Water Crisis: Will Government Changes Help?

https://chinadialogue.net/en/climate/10583-china-is-heading-towards-a-water-crisis-w ill-government-changes-help

Patrick, R. J. (2011). Uneven Access to Safe Drinking Water for First Nations in Canada: Connecting Health and Place through Source Water Protection. Health \& Place, 17, 386-389. https://doi.org/10.1016/j.healthplace.2010.10.005

Peterson, M. S., \& Stephenson, D. J. (1991). Water Resources Development in Developing Countries. Amsterdam: Elsevier Science.

Portney, P. R. (2016). Public Policies for Environmental Protection. New York: Routledge. https://doi.org/10.4324/9781315651477

Postel, S. L., (2000). Entering an era of water scarcity: the challenges ahead. Ecological Application, 10, 941-948.

Reddy, V. R. (2008). Water Pricing as a Demand Management Option: Potentials, Problems and Prospects (pp. 25-46). Strategic Analyses of the National River Linking Project (NRLP) of India, Colombo: IWMI International Water Management Institute.

Ritchie, H., \& Roser, M. (2017). $\mathrm{CO}_{2}$ and Greenhouse Gas Emissions. Our World in Data. https://ourworldindata.org/co2-and-other-greenhouse-gas-emissions

Rogers, P., \& Hall, A. W. (2003). Effective Water Governance (Vol. 7). Stockholm: Global Water Partnership.

Shen, D., \& Speed, R. (2009). Water Resources Allocation in the People's Republic of China. Water Resources Development, 25, 209-225. https://doi.org/10.1080/07900620902868612

Shi, X. (2020). The Safety of Drinking Water in China: Current Status and Future Prospects. China CDC Weekly, 2, 210-215. https://doi.org/10.46234/ccdcw2020.055

Stanway, D. (2019). China Sea Levels, Temperatures Rising amid Climate Change: Government Study.

https://www.reuters.com/article/us-climate-change-china-sealevel/china-sea-levels-tem peratures-rising-amid-climate-change-government-study-idUSKBN1WB0NO

Sun, S., Fang, C., \& Lv, J. (2017). Spatial Inequality of Water Footprint in China: A De- 
tailed Decomposition of Inequality from Water Use Types and Drivers. Journal of Hydrology, 553, 398-407. https://doi.org/10.1016/j.jhydrol.2017.08.020

Sun, Y. Q., Chen, S. Z., Chen, L., Tang, W., \& Zhou, L. C. (2006). Research of Examination and Approval System for Water Drawing Permit's Workflow Based on Web and GIS. China Water \& Wastewater, 22, 46-49.

Walker. A. (2015). What Are Water Rights? https://www.gizmodo.com.au/2015/04/what-are-water-rights/

Wang, S., \& Zhang, Z. (2011). Effects of Climate Change on Water Resources in China. Climate Research, 47, 77-82. https://doi.org/10.3354/cr00965

Wang, Y., Tang, K. W., Xu, Z. X., Tang, Y., \& Liu, H. F. (2009). Water Quality Assessment of Surface Drinking Water Sources in Cities and Towns of China. Water Resources Protection, 25, 1-5.

Wheater, H., \& Evans, E. (2009). Land Use, Water Management and Future Flood Risk. Land Use Policy, 26, S251-S264. https://doi.org/10.1016/j.landusepol.2009.08.019

Wong, S. (2020). Climate Change in China-Statistics \& Facts. Energy \& Environmental Service.

https://www.statista.com/topics/5636/climate-change-in-china/\#dossierSummary_cha pter4

World Bank (2007). Water Supply Pricing in China: Economic Efficiency, Environment, and Social Affordability. New York: The World Bank.

World Bank (2018). Watershed: A New Era of Water Governance in China-Synthesis Report. Washington DC: World Bank.

World Resources Institute (WRI) (2018). Drop by Drop, Better Management Makes Dents in China's Water Stress.

https://www.wri.org/blog/2018/04/drop-drop-better-management-makes-dents-chinas -water-stress

World Resource Institute (WRI) (2020). Country Rankings. https://www.wri.org/applications/aqueduct/country-rankings/

Wu, H., Zhang, X., \& Chen, X. (2012). Approval and Management Mechanism of Water Drawing Allowance and Its Suggestion. Water Resources and Power, 10, 110-112.

Xia, W., Wei, L., \& Deyi, W. (2020). The Blue Paper of Climate Change 2019 in China Is Released. https://reliefweb.int/report/china/blue-paper-climate-change-2019-china-released

Yang, H., \& Zehnder, A. J. (2005). The South-North Water Transfer Project in China: An Analysis of Water Demand Uncertainty and Environmental Objectives in Decision Making. Water International, 30, 339-349. https://doi.org/10.1080/02508060508691874

Yin, Y., Tang, Q., Liu, X., Zhang, X., (2017). Water Scarcity under Various Socio-Economic Pathways and Its Potential Effects on Food Production in the Yellow River Basin. Hydrology and Earth System Sciences, 21, 791-804.

https://doi.org/10.5194/hess-21-791-2017

Zhong, L., \& Mol, A. P. (2010). Water Price Reforms in China: Policy-Making and Implementation. Water Resources Management, 24, 377-396. https://doi.org/10.1007/s11269-009-9451-0

Zhou, Y., Ma, J., Zhang, Y., Qin, B., \& Gao, G. (2017). Improving Water Quality in China: Environmental Investment Pays Dividends. Water Research, 118, 152-159. https://doi.org/10.1016/j.watres.2017.04.035

Zhu, X., Li, Y., Li, M., Pan, Y., \& Shi, P. (2013). Agricultural Irrigation in China. Journal of Soil and Water Conservation Society, 68, 147A-154A.

https://doi.org/10.2489/jswc.68.6.147A 


\section{Appendix A}

Major river basins in the South and North of China with their description and water endowment.

Table A1. River basins in southern China.

Major rivers Description

Originating from the Tibetan plateau and flowing through Qinghai, Tibet, Yunnan, Sichuan, Hubei, Hunan, Jiangxi, Anhui and Jiangsu at a length of $6300 \mathrm{~km}$, Yangtze is

Yangtze considered to be the longest river in China and third largest in the world. It has eight main tributaries and a catchment area of 1.8 million square kilometers, accounting for about $20 \%$ of China's total land area.

The Pearl River is $2214 \mathrm{~km}$ long, and is China's third longest river. It runs through

Pearl Yunnan, Guizhou, Guangxi, Guangdong and empties between Hong Kong and Macau into the South China Sea in which it forms a delta.

\begin{tabular}{|c|c|}
\hline 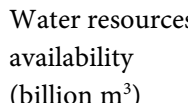 & $\begin{array}{l}\text { Per capita water } \\
\text { availability } \\
\left(\mathrm{m}^{3} / \text { vear capita }\right.\end{array}$ \\
\hline
\end{tabular}

The cradle of Chinese civilization, transportation and irrigation.

Low strain on water (4 per cent) but high susceptibility to water and climate hazards. A repository for some industrial and sewage disposal.

Changes in parts of the regional water tables and drinking qualities.

Intermittent floods, social and ecological problems, particularly at the downstream regions of the Three Gorges Dam.

The River feeds and baths the Greater Bay Areas-it accounts for five percent of the total population of China and 12 percent of the national GDP.

The deterioration in the quality of water continues to worsen. The Pearl River Delta is considered and marked under the Water Ten Plan.

\begin{tabular}{lll} 
Southwest & 504.20 & 31,910 \\
Southeast & 161.96 & 2962 \\
\hline
\end{tabular}

Adapted from CWR (2018), NBSC (2006-2013) and MWR (2006-2011).

Table A2. River basins in northern China.

\begin{tabular}{|c|c|c|c|c|}
\hline Major rivers & Description & $\begin{array}{l}\text { Water resources } \\
\text { availability } \\
\text { (billion } \mathrm{m}^{3} \text { ) }\end{array}$ & $\begin{array}{l}\text { Per capita water } \\
\text { availability } \\
\left(\mathrm{m}^{3} / \text { year. Capita }\right)\end{array}$ & Situational facts \\
\hline Song-Liao & $\begin{array}{l}\text { The Liao River is an important river in the } \\
\text { northeast of China. Having a length of } 1390 \\
\mathrm{~km} \text {, the river flows through Hebei, Jilin and } \\
\text { Liaoning provinces and empties into the } \\
\text { Bohai Sea. }\end{array}$ & 172.07 & 1700 & $\begin{array}{l}\text { Considerable changes have been made to } \\
\text { improve the quality of the water, although } \\
\text { deterioration of the water has not ceased. } \\
\text { Some marked areas are occasionally flooded, but } \\
\text { basin-wide floods are rare. }\end{array}$ \\
\hline Huai & $\begin{array}{l}\text { The } 1078 \mathrm{~km} \text { Huai River rises in the } \\
\text { Tobaishan Mountains, flows through the } \\
\text { provinces of Henan, Anhui and Jiangsu, } \\
\text { and flows into the Yangtze River at Jiangdu, } \\
\text { Yangzhou. The river is famous for its } \\
\text { difficult management. }\end{array}$ & $89.06^{*}$ & 505 & $\begin{array}{l}\text { Pollution and deterioration have been reported } \\
\text { to worsen. } \\
\text { Carcinogenic diseases have been linked to river } \\
\text { pollution in the } 1980 \text { s and } 1990 \text { s. }\end{array}$ \\
\hline Yellow & $\begin{array}{l}\text { The Yellow River, considered to be "the } \\
\text { mother" of the Chinese rivers and the } \\
\text { second longest river in the country, with a } \\
\text { length of } 5.464 \mathrm{~km} \text {, originates from the } \\
\text { western province of Qinghai and crosses } \\
9 \text { provinces before joining the Bohai River } \\
\text { in the province of Shandong. The River is } \\
\text { celebrated for its connection to the rich } \\
\text { culture and civilization of China. }\end{array}$ & 61.06 & 749 & $\begin{array}{l}\text { The cradle of Chinese civilization, transportation } \\
\text { and irrigation. } \\
\text { High strain on water ( } 63 \text { per cent) and high } \\
\text { susceptibility to water and climate hazards. } \\
\text { Diminishing water volumes and changing flow } \\
\text { rates. } \\
\text { Water quality deterioration from intensified use } \\
\text { of agri-chemicals and irrigation. }\end{array}$ \\
\hline
\end{tabular}




\section{Continued}

The Hai River, which flows through Beijing and Tianjin before it discharges into the Bohai Sea which adjoins the Yellow Sea is $1329 \mathrm{~km}$ in length.
The economic and ecological implications stemming from the flood control of Hai have taken a toll on Beijing and Tianjin.

Hai has made considerable progress in improving quality even though it is considered to be the river with the worst category of pollution

Northwest

120.49 5270

Adapted from CWR (2018), NBSC (2006-2013) and MWR (2006-2011). * Including the water transfer into the Hai River Basin and the Huai River Basin. 